\title{
ERGOTAMINE AND APPARENT CORONARY INSUFFICIENCY
}

\author{
BY \\ GUNNAR BIÖRCK
}

From the Second Medical Clinic (Head: Professor G. Nylin), South Hospital, Stockholm

Received June 18, 1947

Since 1942 we have used hypoxæmia tests (Nylin, 1944) as a routine in the clinical examination of patients complaining of symptoms of coronary insufficiency. The results from the first three years' material were reported in this journal (Biörck, 1946). A larger material was investigated (Biörck and Pannier, 1946), and this survey established that the test did not only disclose latent coronary insufficiency in many cases with suspected organic coronary heart disease (" coronary sclerosis ") but also produced apparently pathological electrocardiograms in patients with symptoms of cardiac neurosis in whom there was, on account of their age, very little reason to suspect organic changes in the coronary circulation. The study revealed a relative predominance of women among those who showed a positive hypoxæmia test, and the younger the age group the greater was that relative predominance. There was also a number of cases, mostly women, where the history and the general impression of the patient were suggestive of cardiac or general neurosis.

This impression led us earlier to try to counteract the nervous factors and thus obtain cardiograms that would be less affected by a nervous component. In one case of a possibly climacteric depression we succeeded in abolishing the induced cardiographic changes suggestive of coronary insufficiency by previous injection of morphine-scopolamine.

In a recent investigation Lindgren (1946) has shown that the effect of hypoxæmia on the cardiogram can be diminished in some cases of angina pectoris of the organic type, when the patient has previously received a local anæsthetic at the area of referred pain. This will probably signify that the pain itself, in some instances, induces a vicious circle, and that there is a functional component superimposed upon the organic one, even in cases with true coronary sclerosis.

Although as yet nothing seems to be quite certain regarding the innervation of the coronary vessels (Katz and Jochim, 1939), it may be that both the vagi and the sympathetic carry constrictor and dilator fibres, the distribution of which may be subject to great individual variations. Blocking of the sympathetic was nevertheless regarded as one possible way of studying the problem of the importance of functional factors in some cases of unexpected positive hypoxæmia tests. Nordenfelt (1941) has clearly demonstrated the effect of ergotamine in cases of increased tonus of the sympathetic: cardiograms that suggested coronary insufficiency could in several instances be transformed into normal curves by means of ergotamine, $0.5 \mathrm{mg}$. intravenously or subcutaneously. These findings have been verified by us in a number of cases.

The cardiographic findings in the hypoxæmia test are usually ascribed to the induced anoxæmia or ischæmia of the myocardium. The degree of myocardial anoxæmia is due to a number of factors such as: ventilation, arterial oxygen tension, and arterial $p \mathrm{H}$, as recently shown by Christensen (1947) and Malmström (1947). The findings of Mainzer and Krause (1939) and of Biörck and Pannier (1946) do, however, point to further factors, among which 
hormonal influences, reflex mechanisms, and possibly intermediary tissue metabolism should be considered. This study deals with one of these factors - the sympathetic nervous influence. It has hitherto not been possible for us to carry out determinations of ventilation, arterial oxygen tension, and the $p \mathrm{H}$ of the blood in these cases, and it may be argued that the positive

TABLE I

Clinical Findings in the Ten Patients

\begin{tabular}{|c|c|c|c|c|c|c|c|c|}
\hline $\begin{array}{l}\text { Case } \\
\text { No. }\end{array}$ & $\begin{array}{l}\text { Sex } \\
\text { and } \\
\text { Age }\end{array}$ & Diagnosis & $\begin{array}{c}\text { Blood } \\
\text { Pressure }\end{array}$ & $\begin{array}{c}\text { Sedim. } \\
\text { rate }\end{array}$ & B.M.R. & $\begin{array}{l}\text { Hæmo- } \\
\text { globin } \\
\%\end{array}$ & $\begin{array}{c}\underset{\text { Organic }}{\text { heart }} \\
\text { disease * }\end{array}$ & Neurosis \\
\hline $\begin{array}{l}1 \\
2\end{array}$ & $\begin{array}{l}\text { m. } 14 \\
\text { m. } 20\end{array}$ & $\begin{array}{l}\text { Vegetative instability } \\
\text { Cardiac neurosis? Acute myo- } \\
\text { carditis? }\end{array}$ & $\begin{array}{l}130 / 70 \\
130 / 90\end{array}$ & $\begin{array}{l}1 \\
1\end{array}$ & $\begin{array}{l}-2 \\
+4\end{array}$ & $\begin{array}{l}92 \\
76\end{array}$ & ? & $\begin{array}{c}? \\
\text { yes }\end{array}$ \\
\hline $\begin{array}{l}3 \\
4\end{array}$ & $\begin{array}{l}\text { f. } 26 \\
\text { f. } 26\end{array}$ & $\begin{array}{l}\text { Psychopathia } \\
\text { CO - intoxication. Myocardial } \\
\text { damage? }\end{array}$ & $\begin{array}{l}140 / 80 \\
110 / 60\end{array}$ & $\begin{array}{l}3 \\
8\end{array}$ & $\begin{array}{l}+7 \\
+8\end{array}$ & $\begin{array}{l}78 \\
78\end{array}$ & $?^{*}$ & $\begin{array}{c}\text { yes } \\
?\end{array}$ \\
\hline $\begin{array}{l}5 \\
6 \\
7 \\
8\end{array}$ & $\begin{array}{l}\text { f. } 26 \\
\text { f. } 26 \\
\text { m. } 28 \\
\text { f. } 29\end{array}$ & $\begin{array}{l}\text { Cardiac neurosis? } \\
\text { Cardiac neurosis? } \\
\text { Benzol intoxication. Neurosis } \\
\text { Hypercholesterolæmia + Coron- } \\
\text { ary heart disease? }\end{array}$ & $\begin{array}{l}110 / 80 \\
140 / 70 \\
130 / 85 \\
135 / 80\end{array}$ & $\begin{array}{r}6 \\
12 \\
4 \\
8\end{array}$ & $\frac{-5}{-7}$ & $\begin{array}{l}71 \\
80 \\
82 \\
73\end{array}$ & $\begin{array}{l}? \\
\stackrel{?}{?} * \\
\text { yes } ?\end{array}$ & $\begin{array}{l}? \\
? \\
\text { yes } \\
?\end{array}$ \\
\hline $\begin{array}{r}9 \\
10\end{array}$ & $\begin{array}{l}\text { m. } 35 \\
\text { f. } 53\end{array}$ & $\begin{array}{l}\text { Subchronic myocarditis? } \\
\text { Spondylosis + neurosis + coron- } \\
\text { ary heart disease? }\end{array}$ & $\begin{array}{l}135 / 80 \\
150 / 100\end{array}$ & $\begin{array}{r}17 \\
3\end{array}$ & -2 & $\begin{array}{l}78 \\
77\end{array}$ & $\begin{array}{c}\text { yes? } \\
? \text { ? }\end{array}$ & $\begin{array}{l}\text { yes } \\
\text { yes }\end{array}$ \\
\hline
\end{tabular}

* The electrocardiogram was normal in each case, except that in Case 4 there was a suggestion of myocardial damage or of sympatheticotonia and in Case 7 of vagotonia.

TABLE II

Electrocardiographic Findings Before and After Ergotamine

\begin{tabular}{|c|c|c|c|c|c|c|c|}
\hline \multirow{3}{*}{ Case No. } & \multicolumn{3}{|c|}{ Original hypoxæmia test } & \multicolumn{4}{|c|}{ Hypoxæmia test after ergotamine } \\
\hline & \multicolumn{2}{|c|}{ Electrocardiogram } & \multirow{2}{*}{$\begin{array}{l}\text { Increase in } \\
\text { heart rate } \\
\text { percentage }\end{array}$} & \multicolumn{3}{|c|}{ Electrocardiogram } & \multirow{2}{*}{$\begin{array}{l}\text { Increase in } \\
\text { heart rate } \\
\text { percentage }\end{array}$} \\
\hline & At rest & $\begin{array}{l}\text { Hypoxæmia } \\
\text { test }\end{array}$ & & At rest & $\begin{array}{l}20 \text { min. after } \\
\text { ergotamine }\end{array}$ & $\begin{array}{c}\text { Hypoxæmia } \\
\text { test }\end{array}$ & \\
\hline $\begin{array}{l}1 \\
2 \\
3 \\
4 \\
5 \\
6 \\
7 \\
8\end{array}$ & $\begin{array}{l}\text { normal } \\
\text { normal } \\
\text { normal } \\
\text { normal } \\
\text { normal } \\
\text { normal } \\
\text { normal } \\
\text { normal }\end{array}$ & $\begin{array}{l}\text { positive } \\
\text { positive } \\
\text { positive } \\
\text { positive } \\
\text { positive } \\
\text { positive } \\
\text { positive } \\
\text { positive }\end{array}$ & $\begin{array}{l}40 \\
30 \\
33 \\
33 \\
50 \\
50 \\
50 \\
40\end{array}$ & $\begin{array}{l}\text { normal } \\
\text { normal } \\
\text { normal } \\
\text { normal } \\
\text { normal } \\
\text { normal } \\
\text { normal } \\
\text { normal }\end{array}$ & $\begin{array}{l}\text { the same } \\
\text { the same } \\
\text { the same } \\
\text { the same } \\
\text { the same } \\
\text { the same } \\
\text { the same } \\
\text { slightly } \\
\text { improved }\end{array}$ & $\begin{array}{c}\text { negative } \\
\text { negative } \\
\text { negative } \\
\text { negative } \\
\text { negative } \\
\text { negative } \\
\text { negative } \\
\text { positive }\end{array}$ & $\begin{array}{r}33 \\
45 \\
4 \\
7 \\
45 \\
25 \\
33 \\
75\end{array}$ \\
\hline 9 & normal & positive & 15 & normal & $\begin{array}{l}\text { slightly } \\
\text { improved }\end{array}$ & negative & 30 \\
\hline 10 & normal & positive & 60 & normal & $\begin{array}{l}\text { slightly } \\
\text { improved }\end{array}$ & negative & 50 \\
\hline
\end{tabular}

"Normal" denotes an essentially normal curve.

The increase in heart rate in the hypoxæmia test at the ergotamine test refers to the curve after ergotamine, not to the curve at rest before ergotamine.

The expression "improved "refers to changes in the shape of the cardiogram within the normal limits. 
hypoxæmia tests have been due in all cases to hyperventilation. Although this may have been the cause in some instances it is hard to see how ergotamine could abolish this effect.

The material comprises 10 cases, 4 men and 6 women. Most of them were rather young. Two of them had a slight tendency towards transient hypertension, otherwise there was none with evidence of organic heart disease. Most of them were neurotic or showed a vegetative lability (see Table I). They were submitted to routine cardiographic examination and recommended hypoxæmia tests. Apart from one case (Case 4), whose cardiogram was earlier regarded as indicating either myocarditis or sympatheticotonia, all the curves were normal.

The hypoxæmia test was performed with 9 per cent oxygen in nitrogen for 10 minutes and evaluated according to the criteria of Levy et al. (1941). These 10 cases were selected for ergotamine-hypoxæmia on account of the apparent discrepancy between the age or the history and the result of the test. They were all re-examined with regard to their circulatory system before the procedure, because of the danger of unfavourable reactions, if the patient should have an organic lesion of the coronary arteries (Lindgren, 1947). Only in one case did we encounter any complication with the ergotamine, probably on account of injection into a nerve.

The interval between the first hypoxæmia test and the one with ergotamine has varied from a few days to one month. However, in no case has there been any change in the patient's condition, subjectively or objectively or any special treatment. The cardiogram at rest has in all cases remained essentially the same.

The ergotamine hypoxæmia test has been performed as follows. After a previous curve at rest the patient has been given ergotamine $0.5 \mathrm{mg}$. (Gynergen, Sandoz) intramuscularly or subcutaneously. After 20 minutes a new cardiogram has been taken, after which the hypoxæmia test has started. After 10 minutes a third curve has been taken and the patient given 100 per cent oxygen to breath. Two examples are given in Fig. 1 and 2.

The results of each case are shown in Table II. Out of ten cases not less than nine have shown a negative test after ergotamine. This naturally does not mean that there is no change at all, but the changes are within the limits according to Levy's criteria. The one (Case 8), that remained positive, suffers from a moderate cholesterolæmia and has a family history with several deaths from cardiovascular sclerosis in the fourth decade.

The investigation has given some further evidence in favour of the view that nervous influence, presumably over-activity of the sympathetic which is not uncommon in young people, may give a positive hypoxæmia test. The factors that cause positive results can be

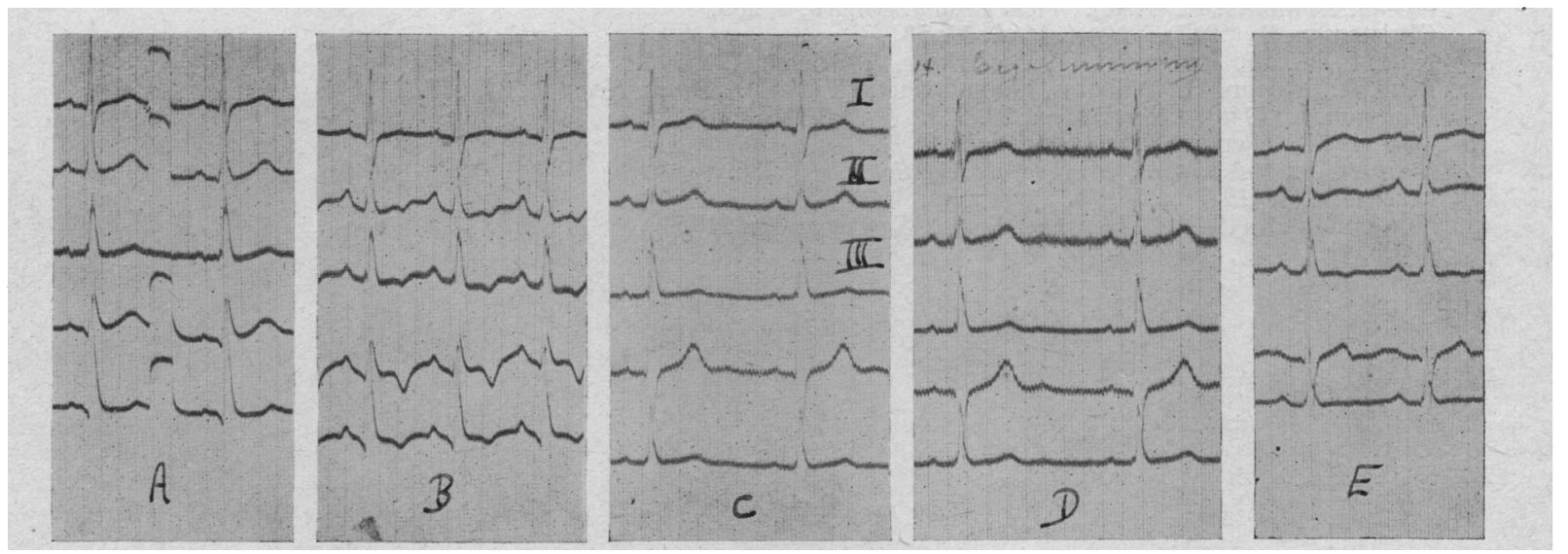

Fig. 1.-Electrocardiograms from Case 1, a boy aged 14, with vegetative instability.

$\begin{array}{llll}\text { (A) At rest. } & \text { (B) After ten minutes' hypoxæmia. } & \text { (C) At rest on a later date. } & \text { (D) Twenty minutes after } 0.5 \text { mg. }\end{array}$ ergotamine. (E) After ten minutes' hypoxæmia.

The five electrocardiograms are in each case I, II, III, and the anterior and posterior chest leads according to Nylin-Nehb. 


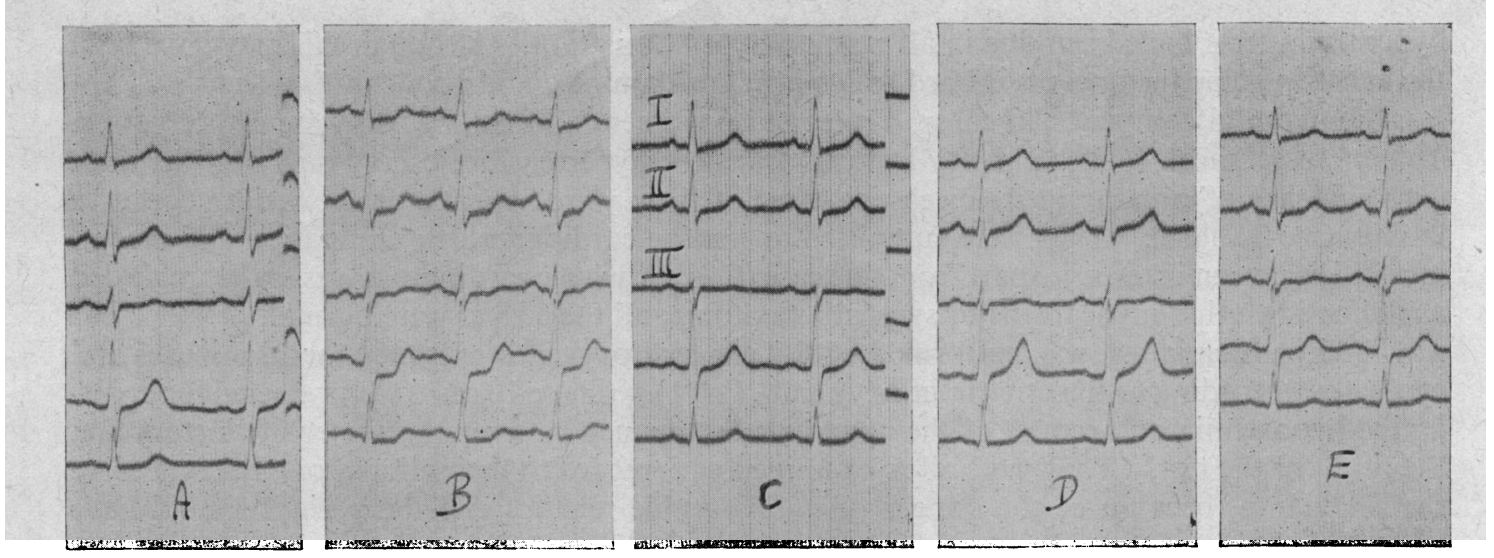

FIG. 2.-Electrocardiograms from Case 2, a woman aged 26 years, with a probable cardiac neurosis.

(A)-(E) as for Fig. 1.

partly paralysed by blocking the sympathetic with ergotamine. Endogenous changes in vegetative tonus may naturally also be one explanation. This may express itself also on the ventilation, which should, therefore, if possible, be studied together with the drug action. This study does not attempt to solve the problem of the vegetative activity on coronary circulation, but merely points to its existence and the possibilities of its clinical exploration.

\section{SUMMARY}

In ten cases with positive hypoxæmia tests where it was questioned if the outcome of the test might not be due to " functional" factors rather than to coronary sclerosis or myocardial disease, a new hypoxæmia test was performed after the injection of ergotamine $0.5 \mathrm{mg}$. In nine of the cases the test after ergotamine was negative. This points to an effect of the sympathetic nervous system in such cases. Further investigations are needed.

Biörck, G. (1946). Brit. Heart J., 8, 17.

\section{REFERENCES}

Chr and Pannier, R. (1946). Acta cardiol. Belgica, 1, 283.

Christensen, B. (1947). Nord. Med., 33, 531.

Katz, L. N., and Jochim, K. (1939). Amer. J. Physiol., 126, 395.

Levy, R., Bruenn, H., Williams, N., and Carr, H. (1941). Amer. Heart J., 21, 634.

Lindgren, I. (1946). Nord. Med., 29, 523.

(1947). Personal communication.

Mainzer, F., and Krause, M. (1939). Cardiologia, 3, 286.

Malström, G. (1947). Thesis, Stockholm.

Nordenfelt, O. (1941). 'Acta med. Scand., Supplementum 119.

Nylin, G. (1944). Cardiologia, 8, 263. 